[Agr. Biol. Chem., Vol. 35, No. 8, p. 1267 1273, 1971]

\title{
Studies on $\kappa$-Casein of Bovine Milk
}

\section{Part III. Some Properties of $\kappa$-Casein and its Complex}

\author{
By Masao Kanamori, Masamitsu Miyoshi, Fumio IBUki \\ and Zensuke MAKI* \\ Department of Agricultural Chemistry, Faculty of Agriculture \\ Kyoto Prefectural University \\ * Department of Food Science, Faculty of Home Economics, \\ Kyoto Prefectural University
}

Received February 22, 1971

\begin{abstract}
$\kappa$-Caseins were prepared by the calcium-ethanol method, the Sephadex method and the urea-sulfuric acid method. Some important properties of $\kappa$-caseins were investigated using isoelectric focusing, starch gel electrophoresis, ultracentrifugation, chemical analysis, stabilization test of $\alpha_{s}$-casein, and rennin treatment. Isoelectric focusing established that $\kappa$-casein had its isoelectric point near $\mathrm{pH} 6.0$ in $6 \mathrm{M}$ urea, usually accompanied by a second peak around $\mathrm{pH}$ 5.6. Ultracentrifugation, however, showed a single peak having a $s_{20, w}$ value of $2.6 \sim 3.8$ in the presence of $6 \mathrm{M}$ urea and of 14.4 in the absence of such dispersing reagents. Normal contents of hexose, sialic acid, phosphorus, and nitrogen were about 1.5, $0.8,0.2$, and $14 \%$, respectively. Relative patterns of amino acid composition were similar in all of the $\kappa$-caseins. In addition, amino acid composition in intact $\kappa$-casein and in the further purified $\kappa$-casein which formed the second peak in DEAE cellulose chromatography were almost identical, indicating that the $\kappa$-casein of the first peak is not an impurity but is one of the components which formed the original $\kappa$-casein complexes. The ability of $\kappa$-caseins to stabilize $\alpha_{s}$-casein in the presence of calcium increased when purified by DEAE cellulose chromatography.
\end{abstract}

Methods for the preparation of $\kappa$-casein were previously examined using the criteria of yield and purity of the $\kappa$-casein obtained. ${ }^{11}$ An important property of $\kappa$-casein, heterogeneity, has been discussed in a previous paper ${ }^{21}$ from the viewpoint of molecular size and charge. In the present experiment, the other interesting properties of $\kappa$-casein were examined and summarized using isoelectric focusing, starch gel electrophoresis, ultracentrifugation, chemical and amino acid analyses, and rennin treatment etc. $\kappa$-Caseins were compared, for

1) M. Kanamori, M. Miyoshi, and F. Ibuki, J. Japan Soc. Food and Nutr., 22, 639 (1969).

2) M. Kanamori, M. Miyoshi, F. Ibuki, and $Z$. Maki, ibid., 24, 96 (1971). the above properties, in relation to their preparative methods. Attention is focused on the role of the weakly adsorbed component in DEAE cellulose chromatography in the construction of the $\kappa$-casein complex.

\section{EXPERIMENTAL}

Preparation of $\kappa$-casein. The calcium ethanol, urea sulfuric acid, and Sephadex methods were used to prepare $\kappa$-casein. Detailed procedures have been reported in a previous paper. ${ }^{11}$ In the present experiment, some $\kappa$-caseins were further purified by DEAE cellulose chromatography. ${ }^{21}$

Isoelectric focusing in $6 \mathrm{M}$ urea. Isoelectric focusing was carried out in a wide range ampholite $\langle\mathrm{pH} 3 \sim$ 10) according to the method described in a previous 
paper. ${ }^{21}$

Starch gel electrophoresis in $6 \times$ urea. General procedures were similar to those described by R. G. Wake and R. L. Baldwin. ${ }^{31}$ One exception is that a different starch concentration was used; 17 percent instead of 13 percent.

Ultracentrifugation. Five $\mathrm{mg}$ of $\kappa$-casein was dissolved in $1 \mathrm{ml}$ of TCU buffer (tris-citrate buffer containing $6 \mathrm{M}$ urea), $\mathrm{pH} 8$. It was centrifuged at 52,000 $\mathrm{rpm}$ in a Beckman Spinco Analytical Ultracentrifuge, Model E. Temperature was kept at $25 \pm 1^{\circ} \mathrm{C}$. Fifty or fifty-five minutes after the maximum speed was reached, 5 photographs were taken every $15 \mathrm{~min}$ for each sample. $s_{20, w}$ values were calculated based on these photographs. In one case, $\kappa$-casein prepared by the calcium-ethanol method was centrifuged at 48,000 $\mathrm{rpm}$ for $25 \mathrm{~min}$ in $0.01 \mathrm{M}$ tris-citrate buffer, $\mathrm{pH}$ 8. The $s_{20, w}$ value of the aggregated $\kappa$-casein not unfolded by urea was also calculated.

Chemical analysis. Hexose was determined by the phenol-sulfuric acid method" using glucose as a standard hexose. Aminoff's thiobarbituric acid method 51 was used to determine sialic acid after the bond between sialic acid and some unknown hexose of $x$ casein had been hydrolyzed at $80^{\circ} \mathrm{C}$ for $60 \mathrm{~min}$ in $0.01 \mathrm{~N}$ sulfuric acid. Phosphorus contents were determined by the Deniges method ${ }^{61}$ using tin chloride as a reducing reagent following complete digestion of $x$ casein in trichloroacetic acid. Nitrogen contents were measured by the micro Kjeldahl method. Tyrosine and tryptophan were measured by the ultraviolet absorption of the $\kappa$-casein solution of a known concentration in $0.1 \mathrm{~N} \mathrm{NaOH}$. This procedure is based on that described by T. W. Goodwin and R. A. Movton. ${ }^{71}$

Amino acid anaiysis. Five $\mathrm{mg}$ of $\kappa$-casein were dissolved in $2 \mathrm{ml}$ of distilled $\mathrm{HCl}$ and then hydrolyzed at $100^{\circ} \mathrm{C}$ for $22 \mathrm{hr}$ and $71 \mathrm{hr}$. Air in the ampule tube containing the $\kappa$-casein solution was replaced by Argon gas

3) R. G. Wake arid R. L. Baldwin, Biochim, Biophys. Acta, 47, 22 (1961).

4) M. Dubois, K. A. Gilles, J. K. Hamilton, P. A. Rebers and F. Smith, Anal. Chem., 28, 350 (1956).

5) D. Aminoff, Biochem. J., 81, 384 (1961).

6) T. Mitsui, H. Mitsuda and T. Hata, "Nogeikagaku Jikkensho," Sangyo Tosho, 1966, p. 103.

7) T. W. Goodwin and R. A. Movton, Biochem. J., 40, 628 (1946). to avoid a minimum oxidation reaction. An amino acid analyzer (Hitachi KLA-3B type) was used to analyze the amino acid composition automatically. Corrections were made for variations in amino acid composition during the hydrolyzing time.

Stabilization test of $\alpha_{\mathrm{g}}$-casein by $\kappa$-casein. The stabilization test was performed with calcium sensitive $\alpha_{s}$-casein $(0.3 \%)$ using varying amounts of $\kappa$-casein in the presence of $0.02 \mathrm{M}$ calcium chloride according to the technique of C.A. Zittle. ${ }^{8}$ )

Rennin reaction. Five tenths $\mathrm{mg}$ of rennin powder was dissolved in $1 \mathrm{ml}$ of $0.1 \mathrm{M}$ phosphate buffer, $\mathrm{pH}$ 7.5 , and $20 \mathrm{mg}$ of $\kappa$-casein was dissolved in $0.5 \mathrm{ml}$ of the same buffer. Twenty five hundredths $\mathrm{ml}$ of the $\kappa$-casein solution was mixed with $0.1 \mathrm{ml}$ of the enzyme solution. The reaction was carried out at $37^{\circ} \mathrm{C}$ for $45 \mathrm{~min}$ and stopped by the addition of $0.21 \mathrm{~g}$ of urea. The reaction product was compared with unreacted $\kappa$-casein in the starch gel electrophoresis.

\section{RESULTS AND DISCUSSION}

\section{Isoelectric focusing of acid casein}

Four peaks were found in the isoelectric focusing of acid casein in $6 \mathrm{M}$ urea. Their

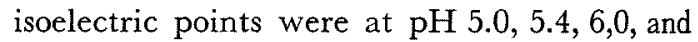
8.2, respectively, as seen in Fig. 1. Fractions of these peaks, when analyzed by starch gel electrophoresis, were found to consist of nearly pure components as shown in Fig. 2. The

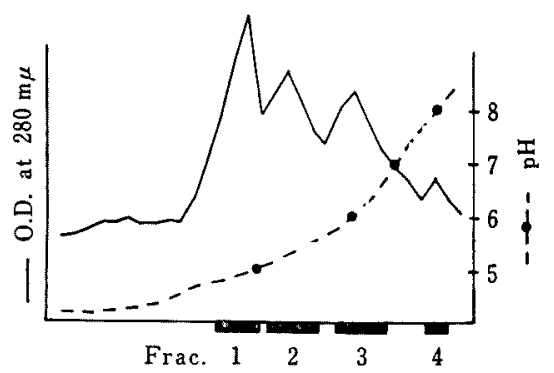

FIG. 1. Isoelectric Focusing of Acid Casein in $6 \mathrm{M}$ Urea.

Column: $3 \times 25 \mathrm{~cm}$. Electrophoresis was performed at $500 \mathrm{~V}$ for $44 \mathrm{hr}$.

8) C. A. Zittle, J. Dairy Sci., 44, 2101 (1961). 


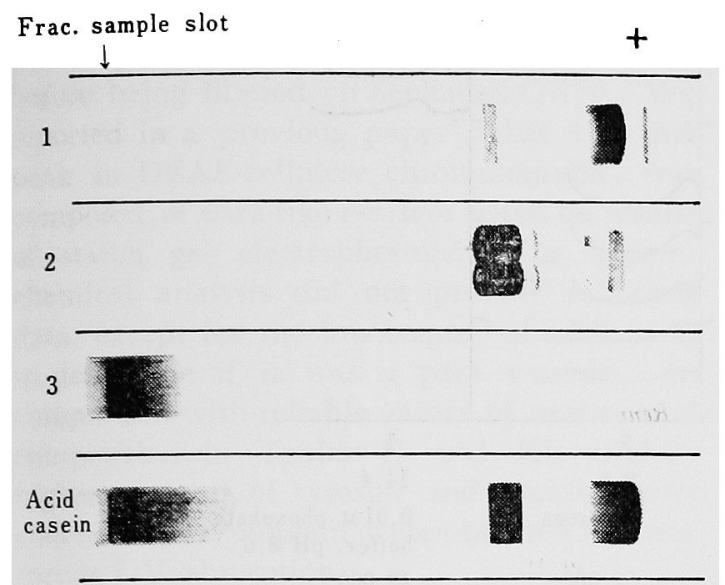

FIG. 2. Starch Gel Electrophoresis of Acid Casein and its Components Obtained by Isoelectric Focusing.

$180 \mathrm{~V}, 10 \mathrm{hr}, \mathrm{pH} 8.6$, in $6 \mathrm{M}$ urea.

$\alpha_{s}, \beta-, \kappa_{-}$, and probably $\gamma$-caseins were well separated by this method, although the $\gamma$-casein, with little information on it, could not be identified as appearing like para $\kappa$-casein. The isoelectric points obtained in this experiment, however, deviated sharply toward the neutral or alkaline sides as compared with those obtained by Tiselius electrophoresis. ${ }^{91}$ Although this type of deviation is naturally expected in the presence of agents such as urea, it newly proved that $\alpha_{s^{-}}$, and $\kappa$-caseins had clearly different isoelectric points. On the other hand, Fig. 1 shows that it is possible to estimate the relative ratio of casein components at a glance in the electrophoretic pattern. The acid casein used in this experiment is considered to be composed of 45 percent of $\alpha_{8}$-casein, 30 percent of $\beta$-casein, 20 percent of $\kappa$-casein and 5 percent of $\gamma$-casein.

\section{Isoelectric focusing of $\kappa$-caseins}

$\kappa$-Caseins exposed to various treatments during their preparation showed that the isoelectric point of their main peaks was around $\mathrm{pH} 6.0$

9) H. E. Swaisgood and J. R. Brunner, J. Dairy Sci., 45, 1 (1962).

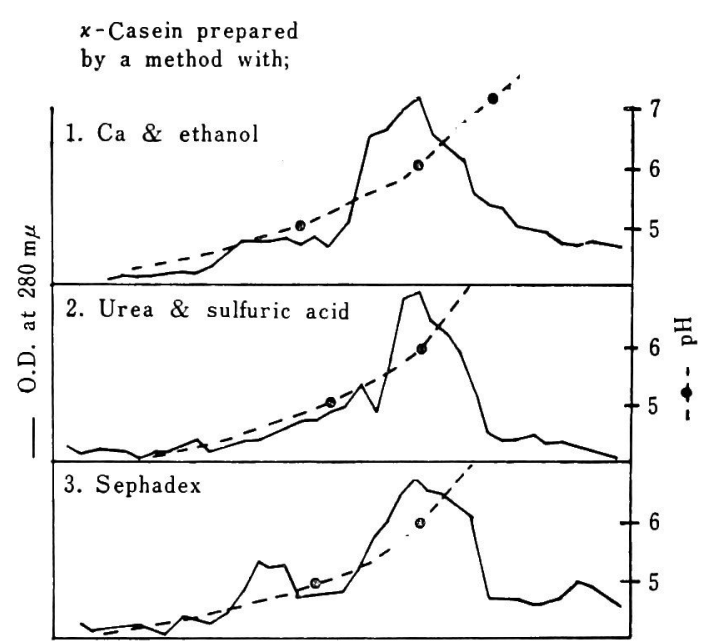

FIG. 3. Isoelectric Focusing of $\kappa$-Caseins in $6 \mathrm{M}$ Urea.

Experimental conditions are shown in Fig. 1.

as expected from the result of isoelectric focusing of acid casein. But, Fig. 3 shows that peaks were much more asymmetrical and broader with a second peak; at $\mathrm{pH} 5.6$ for $\kappa$-casein prepared by the urea-sulfuric acid method, at $\mathrm{pH} 4.9$ for $\kappa$-casein isolated by the Sephadex method and at $\mathrm{pH} 5.2$ for $\kappa$-casein obtained by the calcium-ethanol method.

\section{Ultracentrifugation}

${ }_{\kappa}$-Casein fractioned by DEAE cellulose chromatography into two components with distinctly different molecular sizes has been reported. Results of ultracentrifugation with and without urea showed only a single peak for each $\kappa$-casein as seen in Fig. 4. These somewhat broad peaks indicate that there is some dispersion in molecular size. Therefore, no proof was obtained to show that the two components exist independently in the $\kappa$-casein complex. Effects of differences in methods for the preparation of $\kappa$-casein on its ultracentrifugal properties were found in the degree of molecular size dispersion and in the $s_{20, \mathrm{w}}$ values. $\kappa$-Casein prepared by the urea-sulfuric acid method was interpreted to be composed of the largest and the most homogeneous 


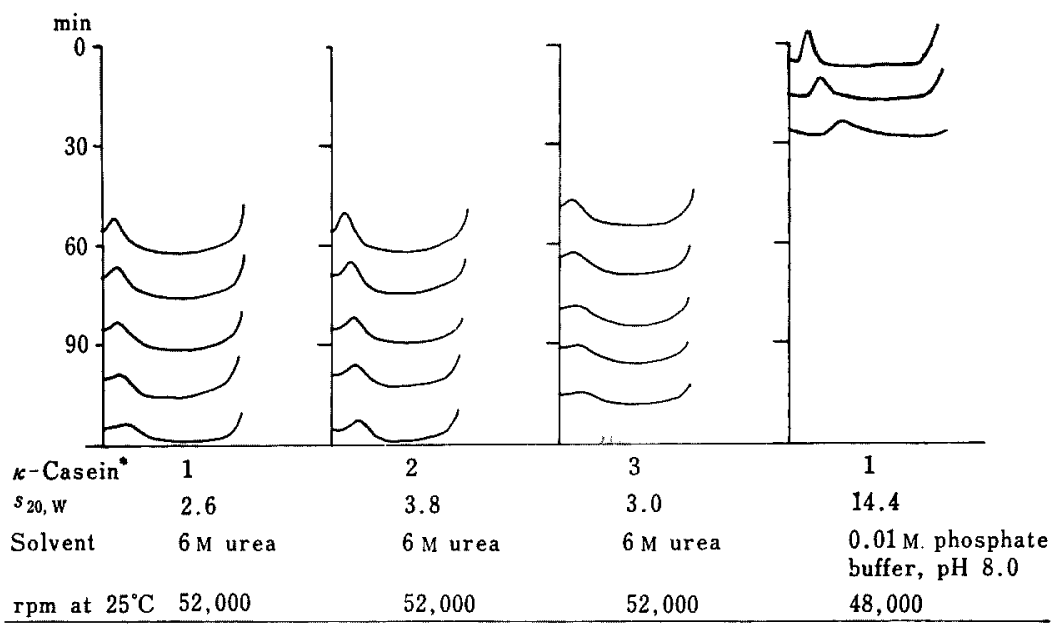

FIG. 4. Ultracentrifugal Analysis of $\kappa$-Caseins.

* see Fig. 3.

molecules with $s_{20, w}$ value of 3.8 . $\kappa$-Casein prepared by the calcium-ethanol method, however, seemed to have the smallest molecules with $s_{20, w}$ value of 2.6. These results are consistent with previous results of Sepharose gel filtration. ${ }^{2)}$ As far as ultracentrifugal properties are concerned, $\kappa$-casein prepared by the Sephadex method was most dispersed or the most diffusible. $\kappa$-Casein showed an $s_{20, w}$ value of 14.4 in the absence of urea suggesting that aggregation occurred with a high degree of dispersion in molecular size.

\section{Chemical analysis}

Results of chemical analysis of $k$-casein are summarized in Table I. It is noteworthy that the hexose contents of $\kappa$-casein prepared by the Sephadex method were abnormally high. The hexose contents of $\kappa$-casein, as reported by other researchers, usually range between 0.7 and $1.5 \%$. Although no further study was made concerning the state of the carbohydrate in the $\kappa$-casein molecule, we believe that the carbohydrate was not free and was bound to the protein moiety. The reason

Table I. Chemical analysis of $\kappa$-Caseins

\begin{tabular}{|c|c|c|c|c|c|c|}
\hline & \multicolumn{5}{|c|}{$\kappa$-Casein* } & \multirow[b]{2}{*}{ Method } \\
\hline & 1 & 2 & 3 & $\begin{array}{c}1 \text { DEAE } \\
\text { chromato. } \\
\text { peak } 1\end{array}$ & $\begin{array}{c}1 \text { DEAE } \\
\text { chromato. } \\
\text { peak } 2\end{array}$ & \\
\hline Hexose $(\%)$ & 1.5 & 1.5 & 15.4 & 1.4 & 1.7 & Phenol-sulfuric acid \\
\hline Sialic acid $(0,0)$ & 0.8 & 0.7 & 0.7 & 0.3 & 1.0 & $\begin{array}{l}\text { Thiobarbituric acid } \\
\text { (Aminoff) }\end{array}$ \\
\hline Phosphorus (\%) & 0.21 & 0.24 & 0.18 & 0.27 & 0.18 & Deniges \\
\hline Nitrogen $(\%)$ & 14.3 & 14.3 & 13.5 & 14.6 & 14.1 & Kjeldahl \\
\hline $\begin{array}{l}\text { Tyrosine } \\
\text { (moles } / 20,000 \mathrm{~g} \text { ) }\end{array}$ & 9.5 & 9.8 & 7.5 & 9.7 & 8.4 & UV absorption \\
\hline $\begin{array}{l}\text { Tryptophan } \\
\text { (moles } / 20,000 \mathrm{~g} \text { ) }\end{array}$ & 0.4 & 0.5 & 0.5 & 0.6 & 0.4 & UV absorption \\
\hline
\end{tabular}

* see Fig. 3. 
for this is that $\kappa$-casein was precipitated three times by acid to remove all soluble materials before being filtered on Sephadex G-150. We reported in a previous paper ${ }^{2)}$ that the first peak in DEAE-cellulose chromatography was composed of para-like $\kappa$-casein based on results of starch gel electrophoresis. The present chemical analysis did not provide sufficient data, except for the low content of sialic acid, to determine if it was a para $\kappa$-casein. In comparison with reliable values of amino acid composition in Tables II and III, slightly higher contents of tyrosine and slightly lower contents of tryptophan were obtained by measuring UV absorption.

\section{Amino acid composition}

There was not much difference in the amino acid composition of $\kappa$-caseins prepared by the three methods as seen in Tables II and III. ${ }$-Casein prepared by the Sephadex method showed lower values in inverse proportion to its higher content of hexose. The relative

Table II. Amino Acid Analysis of $\kappa$-Casein Date are expressed as moles per $20,000 \mathrm{~g}$.

\begin{tabular}{|c|c|c|c|c|}
\hline \multirow{2}{*}{$\begin{array}{c}\text { Amino } \\
\text { acid }\end{array}$} & \multicolumn{3}{|c|}{$\kappa$-Casein* } & \multirow{2}{*}{$\begin{array}{l}\text { Prepared } \\
\text { by Kalan } \\
\text { et al.10) }\end{array}$} \\
\hline & 1 & 2 & 3 & \\
\hline Lys & 8.4 & 9.1 & 6.3 & 9.1 \\
\hline His & 2.9 & 3.1 & 2.2 & 3.0 \\
\hline Arg & 4.7 & 5.1 & 3.6 & 5.0 \\
\hline Asp & 11.2 & 11.3 & 8.8 & 11.0 \\
\hline Thr & 12.1 & 12.7 & 10.2 & 12.1 \\
\hline Ser & 11.0 & 11.6 & 8.7 & 11.0 \\
\hline Glu & 20.0 & 22.1 & 16.0 & 24.9 \\
\hline Pro & 8.6 & 9.4 & 6.8 & 17.5 \\
\hline Gly & 2.6 & 2.6 & 2.1 & 2.6 \\
\hline Ala & 12.3 & 13.2 & 9.8 & 13.4 \\
\hline Cys-Cys & 1.5 & 1.0 & 1.0 & 1.0 \\
\hline Val & 9.1 & 9.4 & 7.5 & 10.2 \\
\hline Met & 1.8 & 1.8 & 1.4 & 1.9 \\
\hline Ileu & 10.2 & 10.7 & 8.2 & 11.5 \\
\hline Leu & 8.1 & 8.5 & 6.2 & 8.7 \\
\hline Tyr & 8.1 & 7.8 & 5.9 & 8.8 \\
\hline Phe & 3.9 & 4.2 & 3.2 & 4.2 \\
\hline
\end{tabular}

* see Fig. 3.
TABle III. Amino Acid ANalysis of $\kappa$-CASein 1 AND ITS COMPONENTS OBTAINED BY DEAECELLULOSE CHROMATOGRAPHY

Data are expressed as moles per $20,000 \mathrm{~g}$.

\begin{tabular}{|c|c|c|c|c|c|}
\hline \multirow{3}{*}{$\begin{array}{l}\text { Amino } \\
\text { acid }\end{array}$} & \multirow{3}{*}{$\begin{array}{c}\kappa \text {-Casein } \\
1\end{array}$} & \multicolumn{4}{|c|}{$\begin{array}{l}\text { Peak in DEAE-cellulose } \\
\text { chromatography }\end{array}$} \\
\hline & & \multicolumn{2}{|c|}{ Native } & \multicolumn{2}{|c|}{ Reduced } \\
\hline & & $\begin{array}{c}2 \\
\text { First } \\
\text { half }\end{array}$ & $\begin{array}{c}2 \\
\text { Second } \\
\text { half }\end{array}$ & 1 & 2 \\
\hline Lys & 8.1 & 7.6 & 7.6 & 8.7 & 7.8 \\
\hline $\mathrm{His}$ & 2.8 & 2.8 & 2.7 & 2.6 & 3.0 \\
\hline Arg & 4.6 & 4.5 & 4.1 & 4.7 & 4.2 \\
\hline Asp & 11.1 & 10.3 & 10.2 & 10.7 & 10.7 \\
\hline Thr & 12.0 & 11.6 & 12.4 & 6.6 & 12.8 \\
\hline Ser & 10.3 & 9.7 & 9.9 & 8.9 & 10.5 \\
\hline Glu & 19.9 & 19.2 & 19.4 & 17.9 & 20.2 \\
\hline Pro & 8.6 & 8.5 & 8.7 & 7.8 & 9.4 \\
\hline Gly & 2.5 & 2.1 & 2.2 & 2.9 & 2.1 \\
\hline Ala & 12.3 & 12.1 & 12.2 & 20.2 & 12.9 \\
\hline Cys-Cys & 1.3 & 1.2 & 1.0 & tr. & tr. \\
\hline Val & 8.9 & 8.8 & 8.7 & 7.4 & 9.8 \\
\hline Met & 1.7 & 1.6 & 1.7 & 1.4 & 1.7 \\
\hline Ileu & 9.7 & 9.8 & 9.8 & 8.6 & 10.6 \\
\hline Leu & 8.0 & 7.5 & 7.3 & 9.5 & 7.5 \\
\hline Tyr & 7.9 & 8.0 & 7.3 & 10.3 & 7.6 \\
\hline Phe & 3.8 & 3.5 & 3.4 & 4.5 & 3.2 \\
\hline
\end{tabular}

ratios of each amino acid, however, are almost the same, indicating that the peptide portions of $\kappa$-caseins are similar in nature. Data from E. B. Kalan and J.H. Woychik ${ }^{101}$ are also shown for comparison. Clear differences in glutamic acid and proline were found. The remarkable decreases in the two amino acids could be due to variations in individual cows. A previous paper ${ }^{2}$ reported that a shoulder appeared at the second peak in DEAE-cellulose chromatography of non-reduced $\kappa$-casein. But the amino acid compositions of both the first and the second halves of peak 2 were nearly consistent with those of the second peak of reduced $\kappa$-casein, indicating that the $\kappa$-casein

10) E. B. Kalan and J. H. Woychik, J. Dairy Sci, 48, 1423 (1965) 
complexes had identical peptide portions. In the amino acid composition of peak 1 , threonine, serine, glutamic acid, proline, valine, and isoleucine decreased in comparison with the unfractionated $\kappa$-casein, but alanine, leucine, tyrosine, and phenylalanine increased. The amino acid composition of para $\kappa$-casein, however, is quite different from that of peak 1 . Considering that no differences in amino acid composition were found between original $\kappa$ casein and the fractionated components in peak 2, it seemed that the component in peak 1 probably forms complexes, similar to those of intact $k$-casein, in combination with such components as that in peak 3 . In another words, it is probable that intact $\kappa$-casein contains some portions susceptible to denaturation. These portions would not usually be released, but could be dissociated into smaller units, i.e. by $\mathrm{DEAE}$-cellulose treatment in $6 \mathrm{M}$ urea.

\section{Stabilization test of $\alpha_{s}$-casein}

$\kappa$-Casein is known to form complexes with

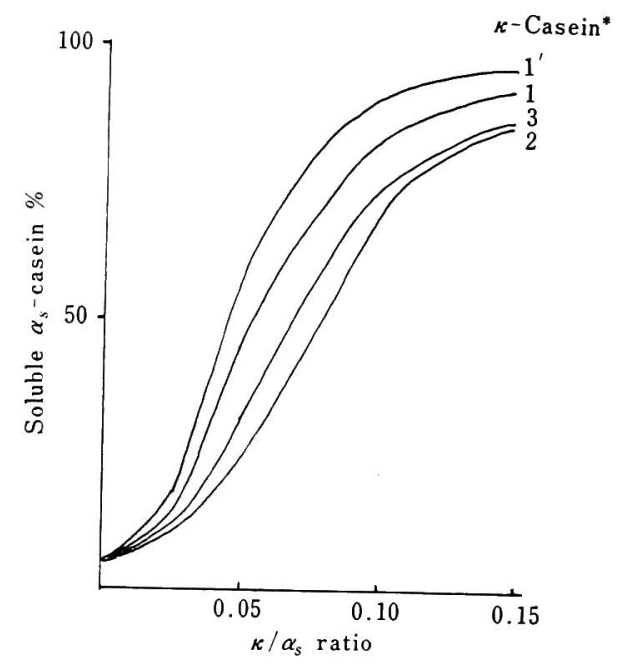

FIG. 5. Solubilization of $\alpha_{s}$-Casein in the Presence of $0.02 \mathrm{M} \mathrm{CaCl}_{2}$ by $\kappa$-Casein.

Casein mixture was incubated at $30^{\circ} \mathrm{C}$ for 15 min and centrifuged at $3000 \times g$.

* see Fig. 3. 1': peak 2 in DEAE chromato. of $k$-casein 1 . $\alpha_{s}$-casein and to solubilize the latter in the presence of calcium. This phenomenon is called "stabilization of $\alpha_{8}$-casein by $k$-casein". Figure 5 shows that all the $\kappa$-caseins were able to stabilize $\alpha_{s}$-casein to a moderate degree. That $\kappa$-caseins prepared by the calcium-ethanol method stabilized the greatest amount of $\alpha_{8}$ casein is understandable if it is taken into consideration that the $\kappa$-casein is dissociated in some measure into smaller complexes, as shown in a previous paper. Dissociation into smaller units, unless it means denaturation, will increase the effective sites for the reaction with $\alpha_{s}$-casein, so that the stability of $\alpha_{s}$-casein increased.

\section{Rennin treatment}

Fractions in peaks 1 and 2 of the DEAEcellulose chromatography were mixed with rennin for $45 \mathrm{~min}$. The reaction products were analyzed together with unreacted fractions by the starch gel electrophoresis. Result in Fig. 6 shows that the component of peak 1 did not react with rennin indicating that the para-like component, the rennin resistent part, wrapped the surface of the $\kappa$-casein complexes. That

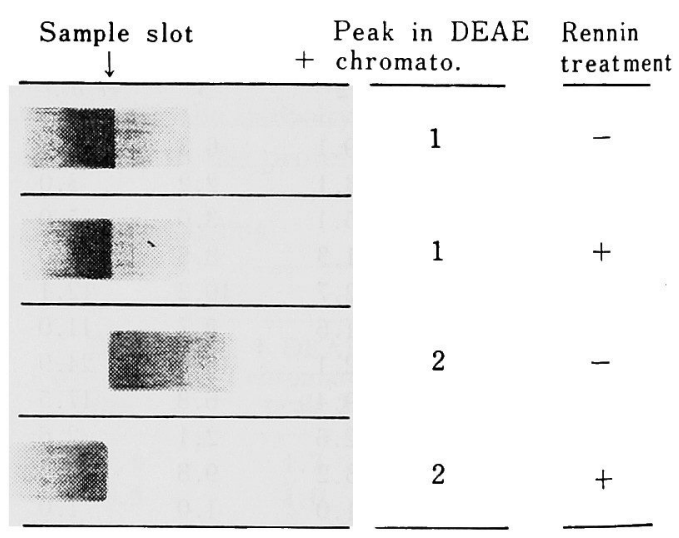

FIG. 6. Starch Gel Electrophoresis Showing the Results of Rennin Action on Component of $\kappa$ Casein 1 Obtained by DEAE-cellulose Chromatography.

$\kappa$-Casein $(10 \mathrm{mg})$ was treated with rennin $(0.05$ $\mathrm{mg}$ ) at $37^{\circ} \mathrm{C}$ for $45 \mathrm{~min}$. Electrophoresis was performed at $\mathrm{pH} 8.6$ in $6 \mathrm{~m}$ urea $(180 \mathrm{~V}, 10 \mathrm{hr})$. 
is why the other minor component of peak 1, completely decomposed by rennin leaving para which moved toward the anode in starch gel $\kappa$-casein. The structures of $\kappa$-casein complexes electrophoresis, was not acted on by rennin. will be discussed again in the later papers.

The component of peak 2, however, was 